Article

\title{
Thermodynamic Modelling of Iron Ore Sintering Reactions
}

\author{
Chunlin Chen ${ }^{1, *}$, Liming Lu $^{1}$ and Kexin Jiao ${ }^{2}$ \\ 1 CSIRO Mineral Resources, Clayton, VIC 3168, Australia; liming.lu@csiro.au \\ 2 School of Metallurgical and Ecological Engineering, University of Science and Technology Beijing, \\ Beijing 100083, China; jiaokexin_ustb@126.com \\ * Correspondence: Chunlin.chen@csiro.au; Tel.: +61-3-9545-8530
}

Received: 20 May 2019; Accepted: 7 June 2019; Published: 13 June 2019

Abstract: Silico-ferrite of calcium and aluminum (SFCA) is one of the most commonly-produced phases in fluxed iron-ore sintering, and has long been regarded as an important bonding phase in industrial sinters. It is thus considered to have a significant effect on sinter quality. In this study, a solid solution model and database has been developed for the SFCA phase, and has been incorporated into the thermodynamic software, Multi-Phase Equilibrium (MPE). MPE calculations were compared with the in situ X-ray powder diffraction (XRD) observations of the formation of SFCA phase during sintering. The effects of the raw material composition, temperature and the oxygen partial pressure on the formation of mineral phases in the sinter, as well as the viscosity of the melt formed during sintering under equilibrium conditions, were modelled using MPE. The results show that the formation of SFCA phase can be promoted by increasing oxygen partial pressure and basicity of the raw material. Increases of $\mathrm{Al}_{2} \mathrm{O}_{3}$ and $\mathrm{MgO}$ content have no significant effect on the SFCA formation under equilibrium condition. The increase of oxygen partial pressure $\left(10^{-3} \mathrm{~atm}\right.$ or above) and basicity also leads to a decrease in melt viscosity, which enhances the fluidity of the melt, and hence, the assimilation of the sinter. However, increases of $\mathrm{Al}_{2} \mathrm{O}_{3}$ and $\mathrm{MgO}$ result in the increase of melt viscosity.

Keywords: thermodynamic modelling; iron ore sinter; SFCA; calcium ferrite; oxygen partial pressure; mineral phases; viscosity

\section{Introduction}

During the iron ore sintering process, the loose raw materials, mixtures of fine ore, limestone flux and coke breeze, are converted into a porous but physically strong cake, which is generally composed of four main phases: iron oxides, ferrites, most of which are a complex silico-ferrite of calcium and aluminum (SFCA), glasses and dicalcium silicate. The properties of iron ore sinter are controlled by the composition and distribution of these mineral phases. In particular, the SFCA is the major bonding phase in iron ore sinter, and plays an important role in influencing key sinter quality parameters such as mechanical strength, reducibility and reduction degradation.

Two types of SFCA phases, SFCA and SFCA-I, were identified in studies on the structure and composition of the SFCA phase [1-3]. Pownceby and Patric [4,5] systematically measured the phase relationship and thermal stability of silico-ferrite of calcium (SFC) and SFCA phases in air within the $\mathrm{Fe}_{2} \mathrm{O}_{3}-\mathrm{CaO}-\mathrm{SiO}_{2}$ and $\mathrm{Fe}_{2} \mathrm{O}_{3}-\mathrm{CaO}-\mathrm{SiO}_{2}-\mathrm{Al}_{2} \mathrm{O}_{3}$ systems, respectively, under equilibrium conditions. Scarlett et al. [6] investigated the reaction sequences in the SFCA phase formation during heating of a sinter from room temperature up to $1533 \mathrm{~K}$ under partially vacuum using in situ XRD technique.

In industrial iron ore sintering, the raw material is heated in a reducing and cooled in an oxidizing atmosphere. Numerous experimental studies have confirmed that the oxygen partial pressure and 
the raw material composition have significant impact on the composition and quantity of the mineral phases present in the sinter [7-10]. Webster and his coworkers [11-16] investigated the SFCA and SFCA-I dynamic formation during heating and cooling of sinter with various compositions under various oxygen partial pressure using the in situ XRD technique.

Some thermodynamic modelling work has been carried out to generate the phase relationships in the $\mathrm{FeOx}-\mathrm{CaO}-\mathrm{SiO}_{2}-\mathrm{MgO}-\mathrm{Al}_{2} \mathrm{O}_{3}$ system [17-20], which provides useful information for understanding the behavior of the melt. However, thermodynamic modelling of the SFCA phase formation during sintering has not been attempted. A thermodynamic model of SFCA phase was developed in the frame work of compound energy formalism by Murao et al. [21].

Multi-Phase Equilibrium (MPE) is a thermodynamic software developed by CSIRO for calculating the multi-phase, multi-components equilibrium. It contains a variety of solution models such as slag, alloy and various solid solutions. It can also estimate the physical properties of the melt, such as the liquidus temperature, primary phase, viscosity and electrical conductivity of the slag [22].

In a previous study [19], MPE was used to predict the effects of sinter composition and the oxygen partial pressure on the liquidus of the melt formed during sintering. In this study, a solid solution model for describing SFCA phase was developed and has been incorporated in MPE.

In this paper, the continued verification of the model on predicting the SFCA stability using experimental data was presented. The MPE software was used to model the reaction sequences in the formation of SFCA phase during iron ore sintering. The modelling results were compared with the data of in situ XRD observations from laboratory studies. Furthermore, the effects of the composition of the raw material, temperature and the oxygen partial pressure on the formation of the mineral phases in the iron ore sinter, as well as the viscosity of the melt formed during sintering, have been modelled.

\section{Modelling of the SFCA Phase}

The name SFCA was initially proposed by Hancart et al. [1] in 1967 for a complex ferrite occurring in iron-ore sinter assemblages with a composition represented by the formula $x \mathrm{Fe}_{2} \mathrm{O}_{3} \cdot \mathrm{ySiO}_{2} \cdot \mathrm{zAl}_{2} \mathrm{O}_{3} \cdot 5 \mathrm{CaO}$ with $x+y+z=12$. The substitution trend for the SFCA solid solution in the $\mathrm{Fe}_{2} \mathrm{O}_{3}-\mathrm{CaO}-\mathrm{Al}_{2} \mathrm{O}_{3}-\mathrm{SiO}_{2}$ system was subsequently proposed and confirmed to follow the plane defined by the end members: $4 \mathrm{CaO} \cdot 3 \mathrm{SiO}_{2}-\mathrm{CaO} \cdot 3 \mathrm{Fe}_{2} \mathrm{O}_{3}-\mathrm{CaO} \cdot 3 \mathrm{Al}_{2} \mathrm{O}_{3}$ (C4S3-CF3-CA3) and with $\mathrm{M}_{14} \mathrm{O}_{20}$ stoichiometry [2-5].

Studies on SFCA morphology have identified two different types of SFCA: one is a low-Fe form that is simply referred to as SFCA, and which exhibits a prismatic morphology; the second is a high-Fe, low-Si form called SFCA-I with platy morphology [3]. SFCA-I is the most desirable bonding phase in iron ore sinter, since it yields higher sinter strength and better reducibility [23].

Despite the importance of the SFCA-I phase in iron ore sinter, the mechanism of its formation, thermal stability and phase boundary are not fully understood. Thermodynamic data on the stability of SFCA-I phase and the relationships of the SFCA-I and its surrounding phases is very limited, and not sufficient for developing a thermodynamic solution model for SFCA-I. Therefore, the phase diagram of SFCA was only assessed in this study, and a solid solution model was developed to describe the SFCA phase.

As confirmed in the literature [2-4], SFCA phase can be defined by $4 \mathrm{CaO} \cdot 3 \mathrm{SiO}_{2}(\mathrm{C} 4 \mathrm{~S} 3), \mathrm{CaO} \cdot 3 \mathrm{Fe}_{2} \mathrm{O}_{3}$ (CF3) and $\mathrm{CaO} \cdot 3 \mathrm{Al}_{2} \mathrm{O}_{3}$ (CA3) end members. A compound energy formalism [24] with three sub-lattices $\left(\mathrm{Ca}^{+2}\right)_{1}\left(\mathrm{CaSi}^{+6}, \mathrm{FeFe}^{+6}, \mathrm{AlAl}^{+6}\right)_{3}\left(\mathrm{O}^{-2}\right)_{10}$ was adopted for describing the SFCA phase in this study.

\section{Model Validation}

\subsection{Validation on the Stability of SFC Phase}

Pownceby and Patrick [4] investigated the thermal stability, solid solution limits and phase relationships of SFC phase $\left(\mathrm{Al}_{2} \mathrm{O}_{3}\right.$ free SFCA phase) in air under equilibrium conditions within the $\mathrm{Fe}_{2} \mathrm{O}_{3}-\mathrm{CaO}-\mathrm{SiO}_{2}$ system using the drop-quench technique. SFC forms a solid solution along a trend line between the theoretical end-members CF3 and C4S3. Figure 1 shows that the maximum solid 
solution range occurs between compositions containing approximately 6.0 through to 11.7 mass \% C4S3 component. The solid solution is stable between $1333 \mathrm{~K}$ and $1513 \mathrm{~K}$. Above $1513 \mathrm{~K}$, the compositional range narrows until the liquidus is reached. As shown in Figure 1, The SFC compositional range was slightly overestimated in the high temperature area and underestimated in the low temperature area by the MPE model. However, the results show that the experimentally determined SFC stability and phase boundary can be adequately described.

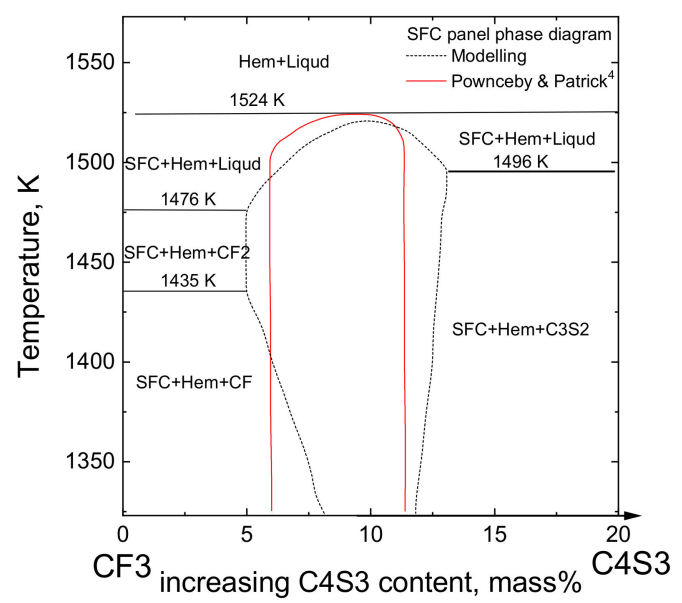

Figure 1. Comparison of the calculated and experimental measured phase stability [4] in the pseudo-binary $\mathrm{CaO} \cdot 3 \mathrm{Fe}_{2} \mathrm{O}_{3}-4 \mathrm{CaO} \cdot 3 \mathrm{SiO}_{2}$ system in air.

Pownceby and Clout [23] found that the SFC phase is stable and coexists with the liquid phase at the $\mathrm{FeO}_{\mathrm{x}}$ corner at $1513 \mathrm{~K}$ in air and oxygen partial pressure of $5 \times 10^{-3} \mathrm{~atm}$. As illustrated in Figure $2 \mathrm{a}, \mathrm{b}$, the stability of $\mathrm{CaSiO}_{3}$ at $1513 \mathrm{~K}$ in air and oxygen partial pressure of $5 \times 10^{-3} \mathrm{~atm}$ was slightly overestimated by the model. However, the results suggest the experimental measured melt region and SFC composition at the $\mathrm{FeO}_{x}$ corner at $1513 \mathrm{~K}$ in air and oxygen partial pressure of $5 \times 10^{-3}$ atm can be represented.
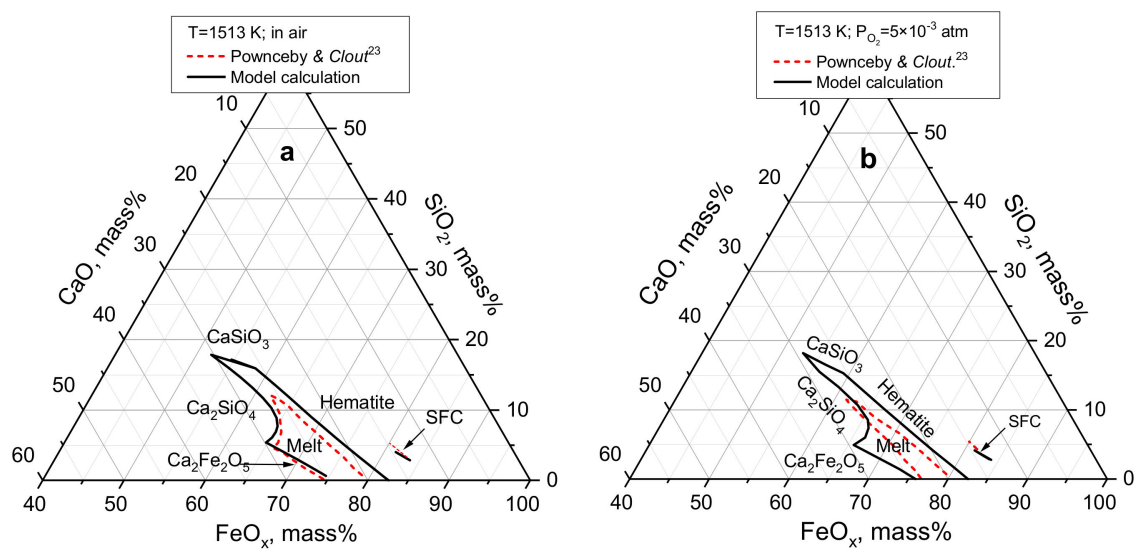

Figure 2. The comparison of the calculated and experimental measured phase stability of $\mathrm{FeO}_{x}-\mathrm{CaO}-\mathrm{SiO}_{2}$ system [23] at $1513 \mathrm{~K}$ and oxygen partial pressure of (a) $0.21 \mathrm{~atm}$ and (b) $5 \times 10^{-3} \mathrm{~atm}$.

\subsection{Validation on the Stability of SFCA Phase}

Patrick and Pownceby [5] expanded their SFC work [4] by introducing $\mathrm{Al}_{2} \mathrm{O}_{3}$ into the system to investigate the solid solution range and thermal stability of SFCA in air within the four components $\mathrm{Fe}_{2} \mathrm{O}_{3}-\mathrm{CaO}-\mathrm{Al}_{2} \mathrm{O}_{3}-\mathrm{SiO}_{2}$ system under equilibrium condition. It was found that the chemical substitution in SFCA phase follows the coupled substitution mechanism: $2\left(\mathrm{Fe}^{3+}, \mathrm{Al}^{3+}\right) \leftrightarrow\left(\mathrm{Ca}^{2+}, \mathrm{Fe}^{2+}\right)+\mathrm{Si}^{4+}$ with 
the greatest range in chemical substitution occurring in the direction of the $\mathrm{Al}^{3+} \leftrightarrow \mathrm{Fe}^{3+}$ exchange (ranging from 0 mass $\% \mathrm{Al}_{2} \mathrm{O}_{3}$ to $\sim 31.5$ mass $\% \mathrm{Al}_{2} \mathrm{O}_{3}$ ). The range of $\mathrm{Al}^{3+} \leftrightarrow \mathrm{Fe}^{3+}$ substitution decreases with increasing temperature. Similar to what was found for the SFC phase, the coupled $\mathrm{Ca}^{2+}$ and $\mathrm{Si}^{4+}$ substitution for $2 \mathrm{M}^{3+}$ is relatively narrow and has a maximum range of between 3 and 11 mass $\%$ C4S3 components. Figure 1 shows that the SFC phase $\left(\mathrm{Al}_{2} \mathrm{O}_{3}\right.$ free SFCA phase $)$ is only stable up to about $1523 \mathrm{~K}$, above that, it will decompose and melt. However, it was reported that the SFCA phase could be stable up to above $1633 \mathrm{~K}$, which demonstrates that $\mathrm{Al}_{2} \mathrm{O}_{3}$ greatly improves the stability of the SFCA phase. As an example, the stability of SFCA at 1513 and $1573 \mathrm{~K}$ predicted by MPE was plotted along with experimental data in Figure 3. There is a good fit of the measured $\mathrm{Al}^{3+} \leftrightarrow \mathrm{Fe}^{3+}$ substitution range at 1513 and $1573 \mathrm{~K}$ by the model. It can also be seen that the gap between the predicted and measured $\mathrm{SiO}_{2}$ solubility range in the $\mathrm{SFCA}$ is relatively large. Considering the narrow range of $\mathrm{SiO}_{2}$ solubility (2 5 mass\%) in SFCA [5], this gap is not expected to cause considerable errors in sintering reaction modelling.
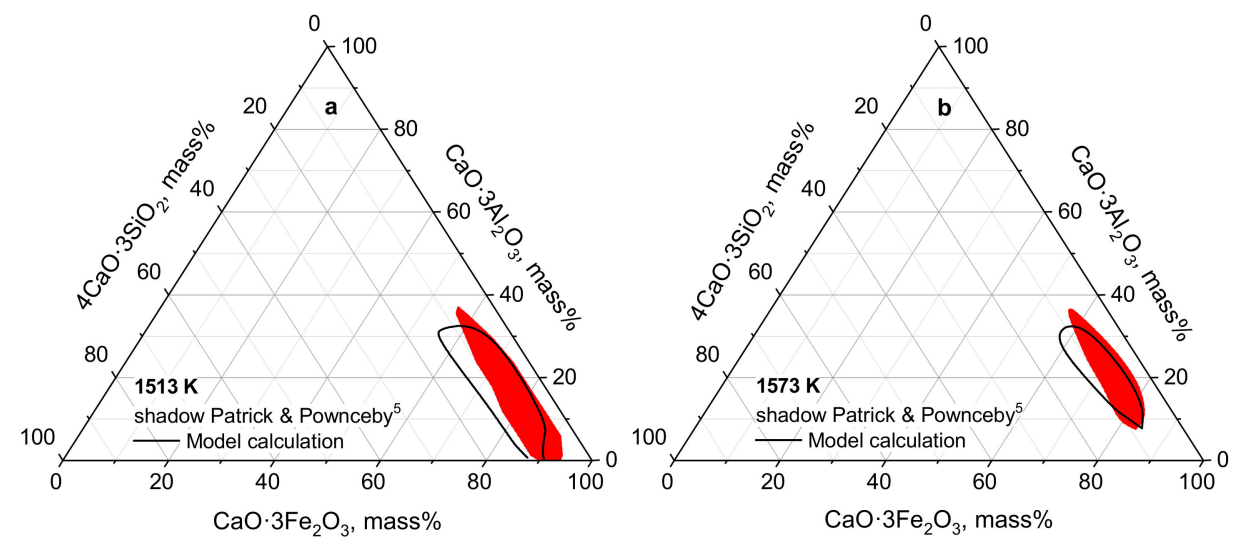

Figure 3. The comparison of the calculated and experimental measured SFCA stability [5] within the CCC plane at (a) $1513 \mathrm{~K}$ and (b) $1573 \mathrm{~K}$.

Figure 4 shows that due to the increasing solubility of $\mathrm{Al}_{2} \mathrm{O}_{3}$ in the melt with increasing temperature, the minimum content of $\mathrm{Al}_{2} \mathrm{O}_{3}$ in SFCA solid solution also increases, while the maximum $\mathrm{Al}_{2} \mathrm{O}_{3}$ solubility remains roughly constant. As shown in Figure 4, there is good agreement between the model calculation and the experimental measurements on the minimum $\mathrm{Al}_{2} \mathrm{O}_{3}$ solubility in SFCA phase.

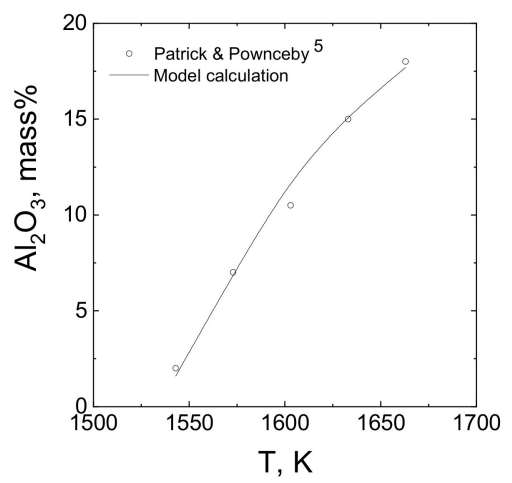

Figure 4. Comparison of the calculated and experimental measured minimum solubility of $\mathrm{Al}_{2} \mathrm{O}_{3}$ in SFCA [5].

\section{Reaction Sequences in the Iron Ore Sintering}

The reaction sequences involved in the formation of SFCA phase during heating of a sinter with a composition of 77.26 mass $\% \mathrm{Fe}_{2} \mathrm{O}_{3}, 14.08$ mass $\% \mathrm{CaO}, 3.56$ mass $\% \mathrm{SiO}_{2}$ and 5 mass $\% \mathrm{Al}_{2} \mathrm{O}_{3}$ 
was investigated by Scarlett et al. [6] using an in situ X-ray diffraction technique under partially vacuum and by Webster et al. [11] at oxygen partial pressure of $5 \times 10^{-3} \mathrm{~atm}$. Starting material compositions were designed to lie within a plane that connects the SFCA end members CF3, CA3 and C4S3. Thermodynamic modelling of the chemical reactions which occur during heating of the same sample was carried out using MPE.

The modelling results in Figure 5 show that the SFCA phase is formed at $1273 \mathrm{~K}$, which is close to the experimental observation from in situ XRD analysis by Scarlett et al. [6]. The Formation of SFCA phase was observed at $1437 \mathrm{~K}$ by Webster et al. [11]. Webster also heated the sample at $1323 \mathrm{~K}$ for $24 \mathrm{~h}$ and quenched and the resulting sample did not contain the SFCA phase. The results suggest that the stability of SFCA was overestimated by model at oxygen partial pressure of $5 \times 10^{-3} \mathrm{~atm}$. Both experimental studies [6,11] show that C2F started to form at 923 to $1044 \mathrm{~K}$ through lime and hematite solid reaction, while the calculated stable phase is CF. This is probably because the system was not reach equilibrium. The presence of $\mathrm{C} 2 \mathrm{~F}$ between $923 \mathrm{~K}$ and $1323 \mathrm{~K}$ suggests that $\mathrm{C} 2 \mathrm{~F}$ is formed first through lime and hematite solid reaction due to its larger driving force compared to the CF reaction at low temperature. Subsequently, C2F reacts with the excess hematite to form CF. Modelling results also show that below $1323 \mathrm{~K}$, the $\mathrm{SiO}_{2}$ reacted with lime to form dicalcium silicate, while $\mathrm{C} 2 \mathrm{~S}$ was not observed in the experiment. This indicates that $\mathrm{CaO}-\mathrm{SiO}_{2}$ solid reaction is slow at low temperatures, and $\mathrm{C} 2 \mathrm{~S}$ quantity is probably too low to be detected in the experiment. Above $1273 \mathrm{~K}$, experimental results by Scarlett et al. [6] show that SFCA started to increase, and CF decreases with increasing temperature. This also reflects the deviation from equilibrium condition in the experiment due to its high heating rate and slow reaction rate of SFCA through solid-solid reaction. The modelling results show that $\mathrm{Al}_{2} \mathrm{O}_{3}$ reacts with $\mathrm{CaO}$ to form CA2 under $1273 \mathrm{~K}$. At $1273 \mathrm{~K}$, SFCA phase starts to form through solid reaction between the $\mathrm{C} 2 \mathrm{~S}, \mathrm{CA} 2, \mathrm{CF}$ and Hematite. The modelling results also show that the liquid phase was formed at $1473 \mathrm{~K}$, which agrees with experimental observations [6,11].

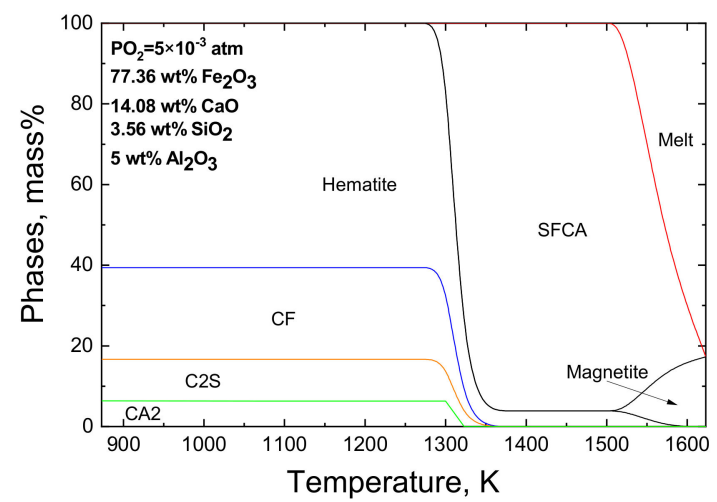

Figure 5. Calculated mineral composition of the sinter at oxygen partial pressure of $5 \times 10^{-3}$ atm under various temperature.

\section{Modelling of the Iron Ore Sintering}

Although the practical sintering reactions do not reach steady-state or equilibrium conditions [25], the phase relations of the sinter from the thermodynamic equilibrium calculation is very useful in sinter composition design for predicting the favorable or likely phases which form, which plays a key role in determining the sinter quality.

MPE was used to calculate the equilibrium position of the reactions occurred in the iron ore sintering process. The quantity of the equilibrated phases such as melt, SFCA and other solid phases under specified sintering condition was obtained. It is well known that the formation of the melt during sintering plays an important role in determining the sinter quality. Therefore, the importance of melt property particularly melt fluidity is generally recognized. The viscosity of the melt formed during sintering was also calculated by using MPE. 
Though the oxygen partial pressure and the temperature corresponding to the iron ore sintering process are not well defined and vary in different zone, it is expected that the oxygen partial pressure will be in the range of $10^{-8}$ to $10^{-3} \mathrm{~atm}$ [23]. Therefore, these two levels of oxygen partial pressure $\left(10^{-8}\right.$ and $\left.10^{-3} \mathrm{~atm}\right)$ were used in the modelling to represent the conditions of sintering process. The modelling conditions are summarized in Table 1.

Table 1. Modelling Conditions.

\begin{tabular}{ccccccc}
\hline $\begin{array}{c}\mathrm{T}, \\
\mathbf{K}\end{array}$ & $\begin{array}{c}\mathrm{PO}_{2} \\
\mathrm{Atm}\end{array}$ & $\begin{array}{c}\mathrm{SiO}_{2,}, \\
\mathrm{Mass} \%\end{array}$ & $\begin{array}{c}\mathrm{CaO}, \\
\mathrm{Mass} \%\end{array}$ & $\begin{array}{c}\mathrm{Al}_{2} \mathrm{O}_{3}, \\
\text { Mass\% }\end{array}$ & $\begin{array}{c}\mathrm{MgO}, \\
\mathrm{Mass} \%\end{array}$ & $\begin{array}{c}\mathrm{Fe}_{2} \mathrm{O}_{3}, \\
\mathrm{Mass} \%\end{array}$ \\
\hline$\sim 1623$ & $10^{-8} \sim 10^{-3}$ & 6 & 10 & 3 & 3 & 78 \\
\hline
\end{tabular}

\subsection{Effect of the Temperature}

The calculated phase assemblages under varied temperatures at oxygen partial pressure of $10^{-8}$ and $10^{-3} \mathrm{~atm}$ are shown in Figure $6 \mathrm{a}, \mathrm{b}$, respectively. The results show that silicate solid phase decreases and liquid melt increases with increasing temperature under two oxygen partial pressures. SFCA phase is not stable at $10^{-8} \mathrm{~atm}$ due to the decreased $\mathrm{Fe}^{3+}$ stability at low oxygen partial pressure. With an oxygen partial pressure of $10^{-3} \mathrm{~atm}$, the SFCA phase is stable at the temperature range of 1273 to $1573 \mathrm{~K}$. Figure $6 \mathrm{a}, \mathrm{b}$ show that at fixed oxygen partial pressure, the change of iron oxide oxidization state with increasing temperature follows hematite to magnetite, and magnetite to wüstite. This agrees with the phase relationships on Fe-O phase diagram.
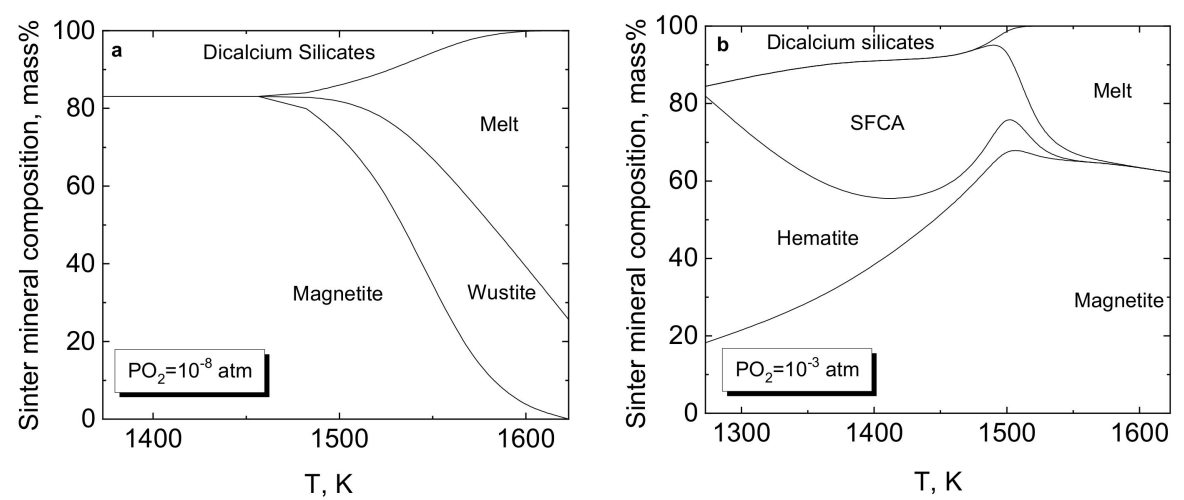

Figure 6. Phase composition of sinter under varied temperature at oxygen partial pressure of (a) $10^{-8}$ atm and (b) $10^{-3}$ atm.

\subsection{Effect of the Oxygen Partial Pressure}

The variation of the quantity of each phase vs oxygen partial pressure is illustrated in Figure 7. Figure $7 \mathrm{a}$ shows that at $1573 \mathrm{~K}$, SFCA phase is only stable at oxygen partial pressure of $10^{-2} \mathrm{~atm}$ and above. It also shows the relationships of the transition of iron oxide from wüstite $(\mathrm{FeO})$ to magnetite $\left(\mathrm{Fe}_{3} \mathrm{O}_{4}\right)$ and hematite $\left(\mathrm{Fe}_{2} \mathrm{O}_{3}\right)$ with increasing oxygen partial pressure. Due to the higher melting point of magnetite than wüstite and hematite, the melt quantity reaches minimum level at oxygen partial pressure of $10^{-5}$ to $10^{-6} \mathrm{~atm}$, where the stability of magnetite reaches maximum. It can also be seen that at the oxygen partial pressure range of $10^{-3}$ to $10^{-7} \mathrm{~atm}$, the dicalcium silicate precipitates from the melt. 

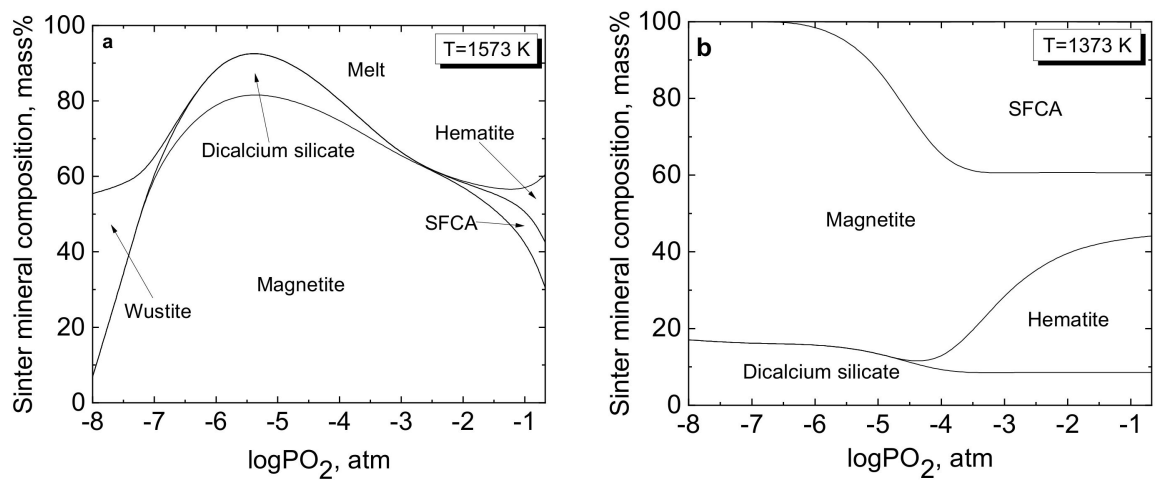

Figure 7. Mineral composition of sinter under varied oxygen partial pressure at temperature of (a) 1573 K and (b) $1373 \mathrm{~K}$.

As shown in Figure $7 \mathrm{~b}$, the quantities of SFCA and silicate phases are pretty constant at $1373 \mathrm{~K}$ and oxygen partial pressure range of 0.21 to $10^{-4} \mathrm{~atm}$, which are about 40 and 10 mass $\%$, respectively. Below $10^{-4} \mathrm{~atm}$, the SFCA phase decreases with decreasing oxygen partial pressure due to the destabilization of ferric oxide, which is the dominant species of SFCA phase. Below $10^{-6} \mathrm{~atm}$ of oxygen partial pressure, the SFCA phase will be decomposed to dicalcium silicate and magnetite.

The calculated compositions of the melt formed at $1573 \mathrm{~K}$ under varied oxygen partial pressure are illustrated in Figure 8. Figure 8a shows that the melt composition changes significantly with the oxygen partial pressure. Since the stability of the magnetite reaches a maximum at oxygen partial pressure of $10^{-5}$ to $10^{-6} \mathrm{~atm}$, the $\mathrm{FeO}_{\mathrm{x}}$ in the melt reaches minimum point, and the $\mathrm{CaO}$ and $\mathrm{SiO}_{2}$ contents in the melt reach maximum. Figure $8 \mathrm{~b}$ shows the variation of the melt viscosity with varied oxygen partial pressure. It is clear that the melt viscosity reaches a maximum at the oxygen partial pressure of $10^{-5}$ to $10^{-6} \mathrm{~atm}$. That is because the viscosity generally increases with increasing of $\mathrm{SiO}_{2}$ in the melt, since $\mathrm{SiO}_{2}$ is a network former in the oxide melt.

As shown in Figure 8b, the $\mathrm{Al}_{2} \mathrm{O}_{3}$ reaches 3 mass $\%$ in the melt at oxygen partial pressure of $10^{-8} \mathrm{~atm}$. As oxygen partial pressure increases, $\mathrm{Al}_{2} \mathrm{O}_{3}$ in the melt decreases and more $\mathrm{Al}_{2} \mathrm{O}_{3}$ reports to the magnetite phase, which reaches a maximum point at oxygen partial pressure of $10^{-6} \mathrm{~atm}$. Above $10^{-6}$ atm oxygen partial pressure, the quantity of magnetite decreased and the SFCA quantity increased as $\mathrm{Al}_{2} \mathrm{O}_{3}$ is transported from the magnetite to SFCA phase. The $\mathrm{Al}_{2} \mathrm{O}_{3}$ concentration in the melt was kept quite constant at about 1 mass $\%$ at the oxygen partial pressure of $10^{-6}$ to $0.21 \mathrm{~atm}$.
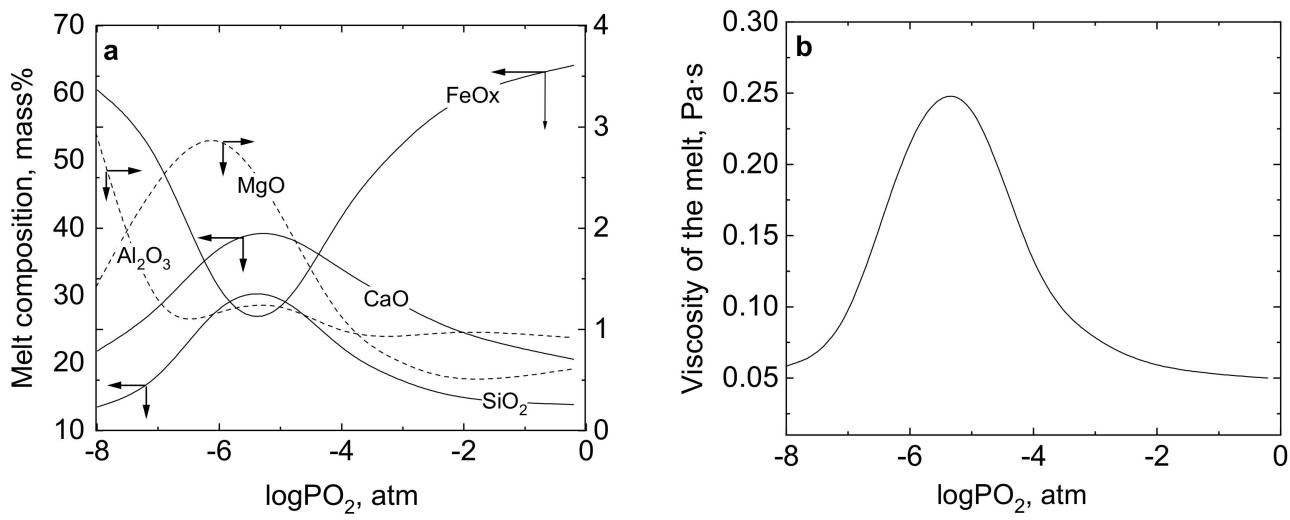

Figure 8. (a) Composition of the liquid melt formed at $1573 \mathrm{~K}$ and (b) the viscosity of the melt under various oxygen partial pressure.

\subsection{Effect of Basicity}

During the calculation, only the $\mathrm{CaO}$ content of sinter was varied to change the basicity $\left(\mathrm{CaO} / \mathrm{SiO}_{2}\right)$ of the raw material. FeOx was allowed to change accordingly to keep all the other species constant. 
A similar condition is applied in cases of modelling the effect of $\mathrm{Al}_{2} \mathrm{O}_{3}$ and $\mathrm{MgO}$ on the mineral phases present in sinter.

Figure 9a shows that the magnetite quantity decreases slightly with increasing basicity in the sinter mixture at $1573 \mathrm{~K}$ and oxygen partial pressure of $10^{-8} \mathrm{~atm}$. The quantity of the liquid melt increases, and wüstite decreases with increasing basicity. This is expected since the composition of the raw material is in the wüstite saturation region at oxygen partial pressure of $10^{-8} \mathrm{~atm}$. Increasing of $\mathrm{CaO}$ content (basicity) moves the sinter mixture composition closer to the melt/wüstite phase boundary, and therefore, increases the melt and decrease the wüstite quantity. Figure $9 \mathrm{~b}$ shows that at $1373 \mathrm{~K}$ and oxygen partial pressure of $10^{-3} \mathrm{~atm}$, the silicates decrease and the SFCA phase increases with increasing of basicity in the raw material. This is because the more $\mathrm{CaO}$ will react with hematite and silica in the silicates to form SFCA phase, causing the hematite and silicates decreases.
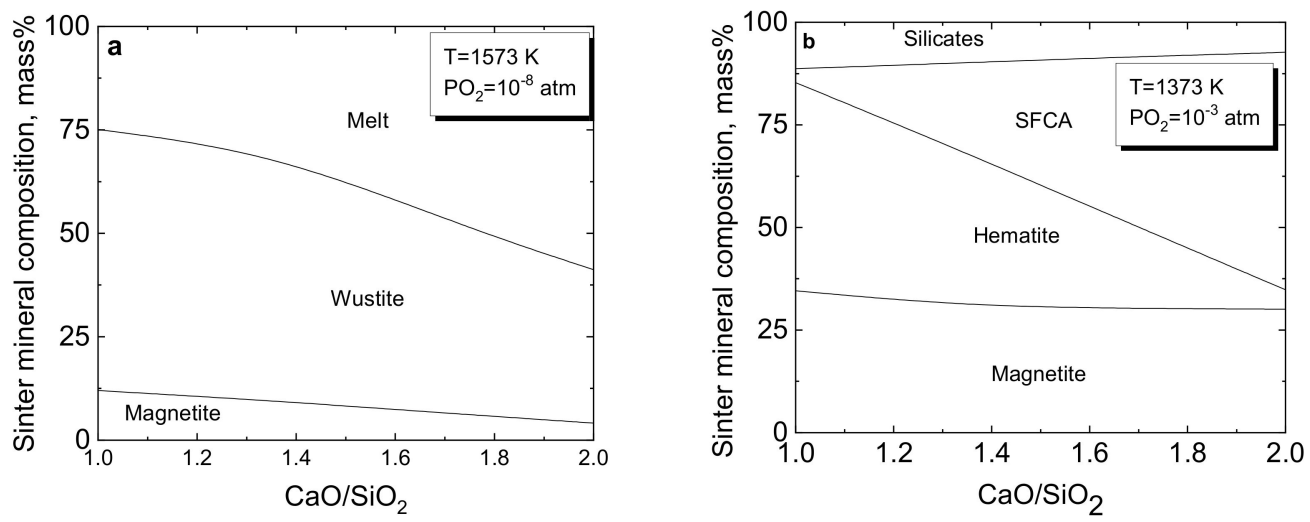

Figure 9. Mineral composition of sinter under varied basicity at temperature of (a) 1573 and (b) $1373 \mathrm{~K}$.

Figure 10a illustrates that the contents of $\mathrm{SiO}_{2}$ and $\mathrm{CaO}$ in the melt formed at $1573 \mathrm{~K}$ and oxygen partial pressure of $10^{-8}$ atm decreases, and $\mathrm{FeO}_{x}$ increases with increasing basicity. Figure $10 \mathrm{~b}$ shows that the increase of the replacement of $\mathrm{SiO}_{2}$ and $\mathrm{CaO}$ with $\mathrm{FeO}_{x}$ causes the viscosity of the melt decreases considerably.
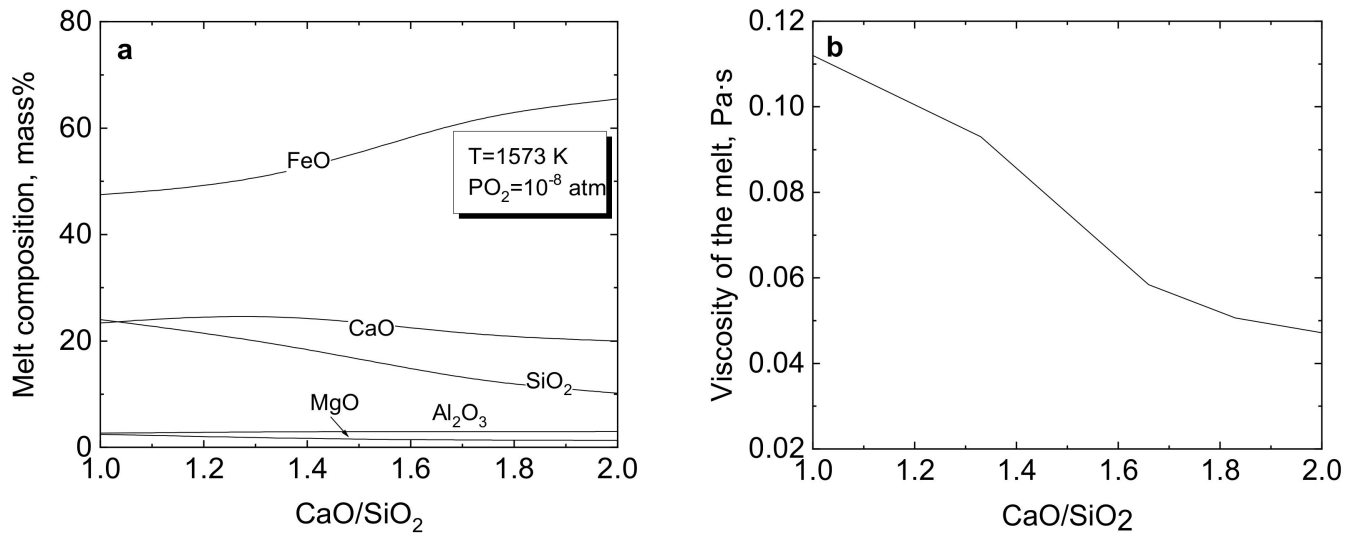

Figure 10. (a) Composition of the liquid melt formed at $1573 \mathrm{~K}$ and oxygen partial pressure of $10^{-8} \mathrm{~atm}$ and $(\mathbf{b})$ the viscosity of the melt under various sinter basicity.

\subsection{Effect of $\mathrm{Al}_{2} \mathrm{O}_{3}$}

Figure 11 shows the variation of the sinter phase composition vs $\mathrm{Al}_{2} \mathrm{O}_{3}$ content at $1573 \mathrm{~K}$ and $1373 \mathrm{~K}$, respectively. As shown in Figure 11a, the melt quantity remains almost constant with differing of $\mathrm{Al}_{2} \mathrm{O}_{3}$ content in the sinter mixture. Patrick and Pownceby's study [5] shows that the presence of $\mathrm{Al}_{2} \mathrm{O}_{3}$ in the $\mathrm{SiO}_{2}-\mathrm{FeOx}-\mathrm{CaO}$ system can stabilize the SFCA phase up to $1663 \mathrm{~K}$ in the air. However, 
the modelling results show that the SFCA phase is not stable at $1573 \mathrm{~K}$ and oxygen partial pressure of $10^{-8}$ atm. Due to the higher stability of $\mathrm{FeAl}_{2} \mathrm{O}_{4}$ than $\mathrm{Fe}_{3} \mathrm{O}_{4}$, the addition of $\mathrm{Al}_{2} \mathrm{O}_{3}$ stabilizes magnetite, and hence, increases its quantity. Figure $11 \mathrm{~b}$ shows that as temperature decreases to $1373 \mathrm{~K}$ and oxygen partial pressure increases to $10^{-3} \mathrm{~atm}$, the SFCA phase precipitates from the system, and the quantities of solid phases presented in the sinter do not change with the $\mathrm{Al}_{2} \mathrm{O}_{3}$ content in the sinter mixture. This minimal effect of the $\mathrm{Al}_{2} \mathrm{O}_{3}$ content on the SFCA quantity was supported by the findings by Choudhary et al [26]. It was reported that the number of phases in final sinter for ores containing 1.4 and 2.2 mass $\% \mathrm{Al}_{2} \mathrm{O}_{3}$ was almost the same, but that the composition and morphology of the phases were markedly different [26].The modelling results reveals that the $\mathrm{Al}_{2} \mathrm{O}_{3}$ solubility in the SFCA phase increases from 7 to 17 mass \% with $\mathrm{Al}_{2} \mathrm{O}_{3}$ content in the raw material increases from 1 to 7 mass\%, while the SFCA phase quantity remains almost constant under equilibrium condition. This result generally agrees with the experimental findings by Patrick and Pownceby [5], which shows that the $\mathrm{Al}_{2} \mathrm{O}_{3}$ solubility in SFCA could reach about 35 mass $\%$ at $1573 \mathrm{~K}$ in the air. However, it was observed that alumina will promote and stabilize SFCA and the SFCA quantity increased with increasing $\mathrm{Al}_{2} \mathrm{O}_{3}$ content $[25,27,28]$. The discrepancy between the modelling results and sintering experiment observation could be caused by the non-equilibrium behavior of the sinter. During the cooling stage, the higher quantity of SFCA phase with relative lower $\mathrm{Al}_{2} \mathrm{O}_{3}$ content could be formed through melt-hematite reaction and melt-magnetite-oxygen reaction at first. The SFCA phase does not reach equilibrium with other phases, and is preserved in the sinter due to its higher cooling rate. Further experiments on quantifying the effect of $\mathrm{Al}_{2} \mathrm{O}_{3}$ content in the raw material on the SFCA quantity under equilibrium is desired for solving the discrepancy.
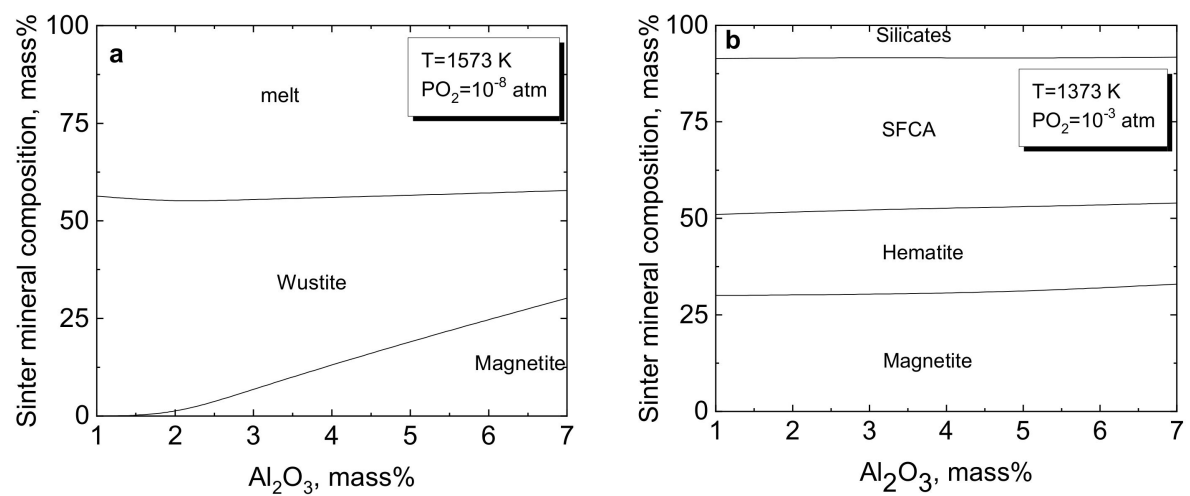

Figure 11. Mineral composition of sinter under varied $\mathrm{Al}_{2} \mathrm{O}_{3}$ at temperature of (a) 1573 and (b) $1373 \mathrm{~K}$.

Since the SFCA phase is not stable at oxygen partial pressure of $10^{-8}$ atm, all the charged $\mathrm{Al}_{2} \mathrm{O}_{3}$ will be distributed between melt and magnetite. As shown in Figure 12a, the increased $\mathrm{Al}_{2} \mathrm{O}_{3}$ content in the sinter mixture leads to the increase of $\mathrm{Al}_{2} \mathrm{O}_{3}$ content in the melt. Figure $12 \mathrm{~b}$ shows that the viscosity of the melt increases with increasing $\mathrm{Al}_{2} \mathrm{O}_{3}$ content in the melt, which suggests that the $\mathrm{Al}_{2} \mathrm{O}_{3}$ behaves like an acidic oxide and network former such as $\mathrm{SiO}_{2}$, rather than as a basic oxide.

\subsection{Effect of $\mathrm{MgO}$}

Figure 13 illustrates that the melt formed at $1573 \mathrm{~K}$ decreases with increasing $\mathrm{MgO}$ in raw material. That is because the addition of $\mathrm{MgO}$ stabilizes the wüstite phase at oxygen partial pressure of $10^{-8} \mathrm{~atm}$, and therefore suppresses the melt and magnetite formation. As shown in Figure 13a, addition of $\mathrm{MgO}$ promotes the reaction of $\mathrm{MgO}$ with hematite to form $\mathrm{MgFe}_{2} \mathrm{O}_{4}$ spinel at the oxygen partial pressure of $10^{-3} \mathrm{~atm}$, while the SFCA and silicate phases were kept pretty constant. 

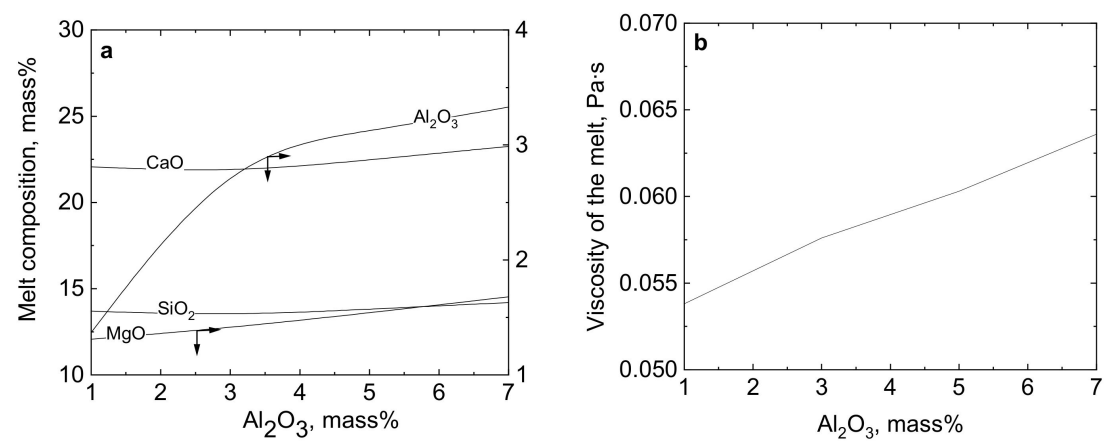

Figure 12. (a) Composition of the liquid melt formed at $1573 \mathrm{~K}$ and oxygen partial pressure of $10^{-8} \mathrm{~atm}$ and (b) the viscosity of the melt under various $\mathrm{Al}_{2} \mathrm{O}_{3}$ content.

The formation of $\mathrm{MgFe}_{2} \mathrm{O}_{4}$ spinel resulted in the stabilization of the magnetite, and therefore, had a negative impact on the SFCA formation. It also needs to be mentioned that $\mathrm{MgO}$ was not defined as a component member in the solid solution model for SFCA phase in MPE. As a result, the predicted effect of MgO on the SFCA content at is small. However, it was reported from Sugiyama's study [29] that $\mathrm{MgO}$ can be dissolved in the SFCA phase by partially substituting $\mathrm{CaO}$. It was also found that $\mathrm{SiO}_{2}$ solubility increases with increasing of $(\mathrm{MgCa}) \mathrm{O}$ in the SFCA. Therefore, it is also possible that the addition of $\mathrm{MgO}$ in the sinter may promote the formation of SFCA, lock more $\mathrm{SiO}_{2}$ in $\mathrm{SFCA}$, and suppress the formation of the silicates.
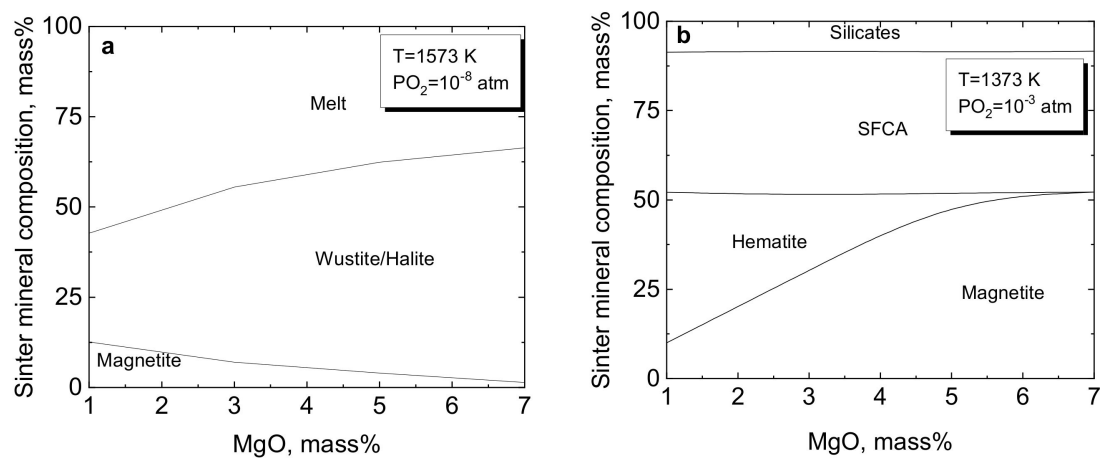

Figure 13. Mineral composition of sinter under varied $\mathrm{MgO}$ at temperature of (a) $1573 \mathrm{~K}$ and (b) $1373 \mathrm{~K}$.

Figure 14a shows that addition of $\mathrm{MgO}$ leads to the increase of $\mathrm{SiO}_{2}, \mathrm{CaO}, \mathrm{Al}_{2} \mathrm{O}_{3}$ and $\mathrm{MgO}$, and decrease of $\mathrm{FeOx}$ in the melt by taking away the wüstite to form wüstite-magnesia halite. As a result, as shown in Figure 14b, the viscosity of the melt increases considerably with increasing $\mathrm{MgO}$ in the raw material.
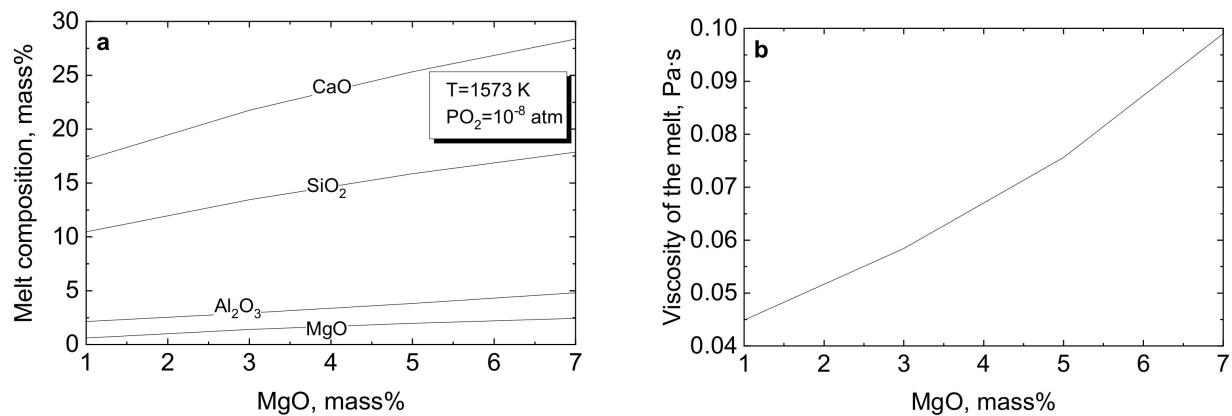

Figure 14. (a) Composition of the liquid melt formed at $1573 \mathrm{~K}$ and oxygen partial pressure of $10^{-8} \mathrm{~atm}$ and (b) the viscosity of the melt under various $\mathrm{MgO}$ content. 


\section{Implication for the Sintering Process}

The volume and properties of the melt formed during sintering depend heavily on temperature, which determines the fuel requirement for sintering. Generally, a greater melt content results in higher degree of assimilation of the ore. However, excess melt formation also leads to poor sintering productivity [30]. At fixed oxygen partial pressure, the stabilities of iron oxides increase in the order of hematite, magnetite and wüstite with increasing temperature. Therefore, lower sintering temperatures favor the solid transition of wüstite to magnetite and hematite, and hence, the formation of SFCA thermodynamically, which was supported by the findings by Yang and Matthews [9]. But due to the high melting point of the magnetite, a high sintering temperature is required to promote the melt formation and ore assimilation for magnetite ore sintering [31]. Hematite ore can be sintered at relative low temperature to generate the required melt [31]. The optimum sintering temperature based on the ore type can be achieved by optimizing the fuel ratio in the sinter mixture.

As illustrated in Figure 7a,b, the stability of SFCA phase increases with increasing of oxygen partial pressure, which is principally controlled by the coke rate in the sinter. Therefore, controlling the coke rate to enhance the oxidation of the sinter and promote the formation of the SFCA phase. Particularly for the magnetite ore sintering, oxidizing of the magnetite to hematite at high oxygen partial pressure would encourage the formation of the SFCA phase. Increasing of $\mathrm{Fe}^{3+}$ level in the raw material by blending of magnetite ore with hematite ore is expected to improve the formation of SFCA phase [10].

Increasing the basicity of the raw material will increase the amount of the melt and decrease its viscosity during the heating stage, and therefore, enhance the assimilation reaction of the sinter and the formation of the SFCA bonding phase, which was supported by experimental studies [8,14]. However, as mentioned above, excess melt has detrimental effect on the sinter property, and the optimum basicity of the raw material needs to be carefully chosen.

\section{Conclusions}

A solid solution model for describing the SCFA phase during iron or sintering was developed. The phase stability of the SFCA, and the phase boundary between the SFCA and its surrounding phases, can be represented reasonably well by the model.

MPE calculation was compared with the data from the in situ XRD observation on the formation of SFCA phase during sintering. The observed increase of the stability range of the SFCA phase and the decrease of the temperature at which it begins to form with increasing $\mathrm{Al}_{2} \mathrm{O}_{3}$ in the sinter can be reproduced by the model. The deviation of the sintering reactions from the equilibrium under experimental conditions contributes to the difference between model calculations and experimental observations.

The effects of the composition of the sintering mixture and the oxygen partial pressure on the formation of the melt and its viscosity, and the formation of the SFCA phase under specified sintering conditions, were modelled by using MPE. It was found that under equilibrium conditions, the formation of the SFCA phase can be promoted by increasing the oxygen partial pressure and the basicity of the raw material. An increase of $\mathrm{Al}_{2} \mathrm{O}_{3}$ and $\mathrm{MgO}$ content does not have a significant effect on the SFCA formation. The modelling results also show that an increase of the oxygen partial pressure $\left(10^{-3} \mathrm{~atm}\right.$ or above) and basicity lead to a decrease of melt viscosity, which enhance the fluidity of the melt, and hence, the assimilation of the sinter. However, an increase of $\mathrm{Al}_{2} \mathrm{O}_{3}$ and $\mathrm{MgO}$ results in an increase of melt viscosity.

Author Contributions: Methodology: C.C., L.L.; software, validation and writing: C.C.; visualization: K.J.; funding acquisition: L.L.

Funding: This research received no external funding.

Acknowledgments: The authors acknowledge the helpful discussions with L. Zhang and S. Jahanshahi.

Conflicts of Interest: The authors declare no conflict of interest. 


\section{References}

1. Hancart, J.; Leroy, V.; Bragard, A. A study of the phases present in blast furnace sinter. Some considerations on the mechanism of their formation. CNRM Metall Rep. 1967,/DS 24/67,3-7.

2. Hamilton, J.D.G.; Hoskins, B.F.; Mumme, W.G.; Borbidge, W.E.; Montague, M.A. The crystal structure and crystal chemistry of $\mathrm{Ca}_{2.3} \mathrm{Mg}_{0.8} \mathrm{Al}_{1.5} \mathrm{Si}_{1.1} \mathrm{Fe}_{8.3} \mathrm{O}_{20}$ (SFCA): Solid solution limits and selected phase relationships of SFCA in the $\mathrm{SiO}_{2}-\mathrm{Fe}_{2} \mathrm{O}_{3}-\mathrm{CaO}\left(-\mathrm{Al}_{2} \mathrm{O}_{3}\right)$ system. N. Jb. Miner. Abh. 1989, 161, 1-26.

3. Mumme, W.G.; Clout, J.M.F.; Gable, R.W. The crystal structure of SCFA-I, $\mathrm{Ca}_{3.18} \mathrm{Fe}^{3+}{ }_{14.66} \mathrm{Al}_{1.34} \mathrm{Fe}^{2+}{ }_{0.82} \mathrm{O}_{28}$, a homologue of the aenigmatite structure type, and new crystal structure refinements of $\beta$-CFF, $\mathrm{Ca}_{2.99} \mathrm{Fe}^{3+}{ }_{14.30} \mathrm{Fe}^{2+}{ }_{0.55} \mathrm{O}_{25}$ and $\mathrm{Mg}$-free SFCA, $\mathrm{Ca}_{2.45} \mathrm{Fe}^{3+}{ }_{9.04} \mathrm{Al}_{1.74} \mathrm{Fe}^{2+}{ }_{0.16} \mathrm{Si}_{0.6} \mathrm{O}_{20}$. N. Jb. Miner. Abh. 1998, 173, 93-117.

4. Pownceby, M.I.; Patrick, T.R.C. Stability of SFC (silico-ferrite of calcium): Solid solution limits, thermal stability and selected phase relationships within the $\mathrm{Fe}_{2} \mathrm{O}_{3}-\mathrm{CaO}-\mathrm{SiO}_{2}$ (FCS) system. Eur. J. Min. 2000, 12, 455-468. [CrossRef]

5. Patrick, T.R.C.; Pownceby, M.I. Stability of silico-ferrite of calcium and aluminum (SFCA) in air-solid solution limits between $1240{ }^{\circ} \mathrm{C}$ and $1390{ }^{\circ} \mathrm{C}$ and phase relationships within the $\mathrm{Fe}_{2} \mathrm{O}_{3}-\mathrm{CaO}-\mathrm{Al}_{2} \mathrm{O}_{3}-\mathrm{SiO}_{2}$ (FCAS) system. Metall. Mater. Trans. B 2002, 33B, 79-89. [CrossRef]

6. Scarlett, N.V.Y.; Pownceby, M.I.; Madsen, I.C.; Christensen, A.N. Reaction sequences in the formation of silico-ferrites of calcium and aluminum in iron ore sinter. Metall. Mater. Trans. B 2004, 35B, 929-936. [CrossRef]

7. Hsieh, L.; Whiteman, J. Effect of oxygen potential on mineral formation in lime-fluxed iron ore sinter. ISIJ Int. 1989, 29, 625-634. [CrossRef]

8. Hsieh, L.; Whiteman, J. Effect of raw material composition on the mineral phases in lime-fluxed iron ore sinter. ISIJ Int. 1993, 33, 33-462. [CrossRef]

9. Yang, L.X.; Matthews, E. Oxidation and sintering of magnetite ore under oxidising conditions. ISIJ Int. 1997, 37, 854-861. [CrossRef]

10. Yang, L.X.; Matthews, E. Sintering reactions of magnetite concentrates under various atmospheres. ISIJ Int. 1997, 37, 1057-1065. [CrossRef]

11. Webster, N.A.S.; Pownceby, M.I.; Madsen, I.C.; Kimpton, J.A. Silico-ferrite of Calcium and Aluminum (SFCA) iron ore sinter bonding phases: New insight into their formation during heating and cooling. Metall. Mater. Trans. B 2012, 43B, 1344-1357. [CrossRef]

12. Webster, N.A.S.; Pownceby, M.I.; Madsen, I.C.; Kimpton, J.A. Effect of oxygen partial pressure on the formation mechanisms of complex Ca-rich ferrites. ISIJ Int. 2013, 53, 774-781. [CrossRef]

13. Webster, N.A.S.; Pownceby, M.I.; Madsen, I.C. In Situ X-ray Diffraction investigation of the formation mechanisms of silico-ferrite of calcium and aluminum and aluminum-I-type (SFCA-I-type) complex calcium ferrites. ISIJ Int. 2013, 53, 1334-1340. [CrossRef]

14. Webster, N.A.S.; Pownceby, M.I.; Madsen, I.C.; Studer, A.J.; Manuel, J.R.; Kimpton, J.A. Fundamentals of silico-ferrite of calcium and aluminum (SFCA) and SFCA-I iron ore sinter bonding phase formation: Effects of $\mathrm{CaO}: \mathrm{SiO}_{2}$ ratio. Metall. Mater. Trans. B 2014, 45B, 2097-2105. [CrossRef]

15. Webster, N.A.S.; Churchill, J.G.; Tufaile, F.; Pownceby, M.I.; Manuel, J.R.; Kimpton, J.A. Fundamentals of silico-ferrite of calcium and aluminum (SFCA) and SFCA-I iron ore sinter bonding phase formation: Effects of titanomagnetite-based ironsand and titanium addition. ISIJ Int. 2016, 56, 1715-1722. [CrossRef]

16. Webster, N.A.S.; Odea, D.P.; Ellis, B.G.; Pownceby, M.I. Effects of gibbsite, kaolinite and Al-rich goethite as alumina sources on silico-ferrite of calcium and aluminum (SFCA) and SFCA-I iron ore sinter bonding phase formation. ISIJ Int. 2017, 57, 41-47. [CrossRef]

17. Kongoli, F.; Yazawa, A. Liquidus surface of $\mathrm{FeO}-\mathrm{Fe}_{2} \mathrm{O}_{3}-\mathrm{SiO}_{2}-\mathrm{CaO}$ slag containing $\mathrm{Al}_{2} \mathrm{O}_{3}, \mathrm{MgO}$, and $\mathrm{Cu}_{2} \mathrm{O}$ at intermediate oxygen partial pressures. Metall. Mater. Trans. B 2001, 32B, 583-592. [CrossRef]

18. Henao, H.M.; Ohno, H.; Itagaki, K. Effect of $\mathrm{Al}_{2} \mathrm{O}_{3}$ or $\mathrm{MgO}$ addition on liquidus of FeOx corner in $\mathrm{FeOx}-\mathrm{SiO}_{2}-\mathrm{CaO}$ slag at 1250 and $1300{ }^{\circ} \mathrm{C}$. In Proceedings of the Sohn International Symposium, San Diego, CA, USA, 27-31 August 2006.

19. Chen, C.; Zhang, L.; Lu, L.; Sun, S. Thermodynamic Calculation of Liquidus Surface of FeOx-CaO-SiO System. ISIJ Int. 2010, 50, 1523-1531. [CrossRef] 
20. Hidayat, T.; Shishin, D.; Decterov, S.A.; Jak, E. Critical thermodynamic re-evaluation and re-optimization of the $\mathrm{CaO}-\mathrm{FeO}-\mathrm{Fe}_{2} \mathrm{O}_{3}-\mathrm{SiO}_{2}$ system. CALPHAD 2017, 56, 58-71. [CrossRef]

21. Murao, R.; Harano, T.; Kimura, M.; Jung, I. Thermodynamic modeling of the SFCA phase $\mathrm{Ca}_{2}(\mathrm{Fe}, \mathrm{Ca})_{6}(\mathrm{Fe}, \mathrm{Al}, \mathrm{Si})_{6} \mathrm{O}_{20}$. ISIJ Int. 2018, 58, 259-266. [CrossRef]

22. Zhang, L.; Jahanshahi, S.; Sun, S.; Chen, C.; Bourke, B.; Wright, S.; Somerville, M. CSIRO's multiphase reaction models and their industrial applications. JOM 2002, 54, 51-56. [CrossRef]

23. Pownceby, M.I.; Clout, J.M.F. The importance of fine ore chemical composition and high temperature phase relations. In Proceedings of the Iron Ore 2002, Perth, Australia, 9-11 September 2002; pp. 209-215.

24. Hillert, M. The compound energy formalism. J. Alloys Compd. 2001, 320, 161-176. [CrossRef]

25. Loo, C.E.; Williams, R.P.; Matthews, L.T. Influence of material properties on high temperature zone reactions in sintering of iron ore. Trans. Inst. Min. Metall. C 1992, 101, c7-c16.

26. Choudhary, M.; Bhattacharjee, D.; Bannerjee, P.; Lahiri, A. Effect of variation of alumina on development of phases during iron ore sintering. ISIJ Int. 2008, 48, 1804-1806. [CrossRef]

27. Hessien, M.M.; Kashiwaya, Y.; Ishii, K.; Nasr, M.I.; El-Geassy, A.A. Sintering and heating reduction processes of alumina containing iron ore samples. Ironmak. Steelmak. 2008, 35, 191-204. [CrossRef]

28. Lu, L.; Holmes, R.J.; Manuel, J.R. Effects of Alumina on Sintering Performance of Hematite Iron Ores. ISIJ Int. 2007, 47, 349-358. [CrossRef]

29. Sugiyama, K.; Monkawa, A.; Sugiyama, T. Crystal Structure of the SFCAM Phase $\mathrm{Ca}_{2}(\mathrm{Ca}, \mathrm{Fe}, \mathrm{Mg}, \mathrm{Al})_{6}$ $(\mathrm{Fe}, \mathrm{Al}, \mathrm{Si})_{6} \mathrm{O}_{20}$. ISIJ Int. 2005, 45, 560-568. [CrossRef]

30. Otomo, T.; Takasaki, Y.; Sato, H. Granule design for the sintering with less amount of liquid phase formation. ISIJ Int. 2009, 49, 659-666. [CrossRef]

31. Clout, J.; Manuel, J. Fundamental investigations of differences in bonding mechanisms in iron ore sinter formed from magnetite concentrates and hematite ores. Powder Technol. 2003, 130, 393-399. [CrossRef]

(C) 2019 by the authors. Licensee MDPI, Basel, Switzerland. This article is an open access article distributed under the terms and conditions of the Creative Commons Attribution (CC BY) license (http://creativecommons.org/licenses/by/4.0/). 